\title{
PENGARUH STRES KERJA DAN KESEMPATAN PROMOSI TERHADAP TURNOVER INTENTION PADA CV. ANISA FADLY KABUPATEN PADANG PARIAMAN
}

\author{
M. Rifky Akbar, Riri Mayliza \\ Sekolah Tinggi Ilmu Ekonomi "KBP" \\ ririmayliza@akbpstie.ac.id \\ m.rifkyakbar@gmail.com
}

\begin{abstract}
The research aimed to know the impact of job stress and promotion opportunity on turnover intention of $C V$. Anisa Fadly Kabupaten Padang Pariaman. This research was a sampling research used 49 respondents and sample saturated method. The data of research were collected by questionnaire, while the data analysis used multiple regression analysis. The result showed that job stress variable has positive $(10,872>1,67655)$ and significant $(0,000<0,05)$ affect to turnover intention. The variable promotion opportunityon has negative $(-0,17)<(1,67655)$ and insignificant $(0,986>0,05)$ affect to turnover intention. From this research obtained $R$ value of 0,717, it means that 71,7\% turnover intention variable can be explained by independent variable that is job stress and promotion opportunityon and the rest that is equal to $28,3 \%$ explained by variables other then equation.
\end{abstract}

Keywords : Job stress, Promotion Opportunity, Turnover Intention

\section{PENDAHULUAN}

Sumber daya manusia mempunyai fungsi di dalam perusahaan yaitu sebagai pemikir, perencana, dan pengendali aktivitas perusahaan karena memiliki bakat, tenaga dan kreatifitas yang sangat dibutuhkan oleh perusahaan untuk mencapai tujuan. Sumber daya manusia sangat berfungsi bagi setiap perusahaan untuk membantu perusahaan dalam mencapai tujuan yang telah ditetapkan perusahaan. Sumber daya manusia merupakan salah satu bagian dari kemajuan ilmu manajemen yang lebih berfokus kepada pengaturan peranan sumber daya manusia di dalam organisasi. Sekarang ini dituntut sumber daya manusia yang kompeten yang memiliki motivasi dan pengalaman kerja yang terampil dalam menjalankan peran dan fungsinya baik untuk individual maupun tujuan organisasi.

Sumber daya manusia dikelola untuk menjadikannya aset yang paling berharga bagi perusahaan bukanlah hal yang mudah. Banyak masalah-masalah pengelolaan SDM ditemukan pada praktiknya, salah satu permasalahan yang banyak ditemukan hampir disetiap perusahaan adalah berkaitan dengan turnover atau tingkat keluar masuknya karyawan di perusahaan. Permasalahan ini secara terus menerus dapat 
menimbulkan masalah baru yang disebut dengan turnover intention atau kecenderungan keluar masuknya karyawan pada suatu perusahaan.

Menurut Syahronica, Hakam, \& Ruhana (2015), turnover intention adalah suatu keinginan yang timbul dari diri karyawan untuk segera meninggalkan perusahaan secara sukarela, keinginan ini dipicu oleh berbagai faktor, seperti ingin mendapatkan kompensasi yang lebih, keinginan karena masalah keluarga, dan sebagainya. Turnover intention bisa jadi dilakukan secara sukarela atau pun tidak. Secara sukarela yaitu ketika ada niatan dari karyawan untuk merencanakan keluar dari organisasinya dengan tujuan untuk memilih berkarir di perusahaan lain. Hal ini biasanya terjadi karena karyawan memiliki pilihan alternatif terbaik untuk masa depannya. Sedangkan yang bukan sukarela adalah ketika organisasi tidak puas dengan kinerja karyawannya dan memutuskan untuk memberhentikannya.

Ada banyak variabel yang menjelaskan terjadinya turnover intention di suatu perusahaan, salah satu faktor pendorong terjadinya turnover intention adalah stres kerja, dengan kondisi seperti beban kerja yang terlalu berat, waktu kerja yang mendesak dan berlebih, sehingga dapat mendorong munculnya stres kerja pada karyawan. Setelah penulis melakukan observasi, adanya beban kerja yang cukup tinggi dan waktu kerja yang melebihi standar jam kerja membuat karyawan CV. Anisa Fadly merasa terbebani dengan hal tersebut yang menyebabkan terjadinya turnover intention setiap tahunnya. CV. Anisa Fadly tidak setiap bulannya mendapatkan proyek dari pemerintah dan terkadang ada proyek yang berada diluar daerah atau jauh dari tempat tinggal karyawan, hal ini mendorong terjadi stres kerja dimana karyawan yang telah memiliki keluarga harus beralih profesi dan mencari pekerjaan lain apabila proyek tidak ada dalam jangka waktu yang lama.

Selanjutnya, variabel lain yang juga berkaitan pengaruhnya terhadap turnover intention adalah kesempatan promosi. Kesempatan promosi merupakan suatu kesempatan yang diberikan kepada karyawan untuk jabatan dan posisi yang lebih tinggi dari posisi sebelumnya dengan diikuti tanggung jawab yang tinggi juga. Setelah penulis melakukan observasi pada CV. Anisa Fadly, didapat dari informasi yang bersumber dari karyawan, bahwa tingkat promosi yang terjadi terbilang rendah. Sebagian pemimpin CV. Anisa Fadly dari tingkat pelaksana, juru ukur, juru hitung, admin dan keuangan, dan logistik di dapat melalui rekruitmen dari luar perusahaan karena jabatan-jabatan tersebut harus sesuai dengan tingkat pendidikan dan keahlian yang bergerak dalam bidang yang sesuai dengan yang dibutuhkan perusahaan, adapun keahlian yang dimiliki kebanyakan dari mahasiswa lulusan dari bidang sesuai dengan yang dibutuhkan perusahaan dan hanya karyawan yang telah lama bekerja yang mendapatkan kesempatan promosi. Kebanyakan karyawan yang keluar dari CV. Anisa Fadly ini memilih alasan yaitu untuk mendapatkan pertumbuhan karir yang lebih baik dan kesempatan promosi di tempat kerja lain.

Melihat adanya peluang karir di luar organisasi dan kurangnya kesempatan kemajuan karir di dalam organisasi saat ini, meningkatkan keinginan karyawan untuk meninggalkan organisasinya. Apabila kurangnya kesempatan promosi menjadi faktor yang paling memengaruhi terjadinya turnover intention karyawan. Kotrak kerja di CV. Anisa Fadly tidak belangsung lama atau dalam jangka waktu tertentu, apabila 
perusahaan mendapatkan proyek dari dari pihak tertentu, maka karyawan dapat melakukan pekerjaannya.

Pada tabel berikut ini memaparkan tingkat persentase turnover karyawan CV. Anisa Fadly.

Tabel 1

Data Turnover Karyawan CV. Anisa Fadly Tahun 2013 - 2017

\begin{tabular}{|c|c|c|c|}
\hline Tahun & Jumlah Karyawan & $\begin{array}{l}\text { Karyawan } \\
\text { Keluar }\end{array}$ & \% Karyawan Keluar \\
\hline 2013 & 76 & 10 & $13.16 \%$ \\
\hline 2014 & 79 & 6 & $7.6 \%$ \\
\hline 2015 & 69 & 13 & $18.9 \%$ \\
\hline 2016 & 58 & 16 & $27.6 \%$ \\
\hline 2017 & 49 & 17 & $34.7 \%$ \\
\hline
\end{tabular}

Sumber : Data CV. Anisa Fadly 2017

Dari data diatas terjadi peningkatan turnover karyawan pada CV. Anisa Fadly yang terjadi setiap tahunnya. Oleh karena itu, penulis tertarik untuk melakukan penelitian di CV. Anisa Fadly karena tingkat turnover intention sangat tinggi setiap tahunnya. Apakah stress kerja dan kesempatan promosi berpengaruh terhadap keluarnya karyawan. Sehingga alasan tersebut penulis memilih judul "Pengaruh Stres Kerja dan Kesempatan Promosi terhadap Turnover Intention pada CV. Anisa Fadly"

Dari latar belakang masalah yang telah diuraikan, maka rumusan masalah dalam penelitian pengaruh stres kerja dan kesempatan promosi terhadap turnover intention adalah sebagai berikut :

1. Apakah stres kerja berpengaruh terhadap turnover intention pada CV. Anisa Fadly Kabupaten Padang Pariaman?

2. Apakah kesempatan promosi berpengaruh terhadap turnover intention pada CV. Anisa Fadly Padang Pariaman ?

\section{TINJAUAN PUSTAKA}

\section{Turnover Intention}

\section{Pengertian Turnover Intention}

Menurut Saeka \& I Wayan Suana (2016), turnover intention merupakan keinginan karyawan untuk meninggalkan perusahaan dan mencoba untuk mencari pekerjaan lain yang lebih baik dari sebelumnya

\section{Indikator Turnover Intention}

Menurut Nazenin \& Palupiningdyah (2014), ada tiga indikator yang mempengaruhi turnover intention yaitu:

1. Adanya niat untuk keluar

2. Pencarian pekerjaan 


\section{Stres Kerja}

\section{Pengertian Stres Kerja}

Menurut Mahardiani \& Pradhanawati (2013) Stres kerja adalah perasaan yang menekan atau merasa tertekan yang dialami karyawan dalam menghadapi pekerjaan..

\section{Indikator Stres Kerja}

Menurut Hakim \& Darmawati (2015), ada beberapa indikator dalam pengukuran stres kerja, yaitu:

1. Konflik Peran

2. Karakteristik Tugas

3. Beban Kerja

\section{Kesempatan Promosi}

\section{Pengertian Kesempatan Promosi}

Menurut Chairy \& Octora (2013), mendefinisikan promosi sebagai proses perubahan dari satu pekerjaan kepekerjaan lain dalam wewenang dan tanggung jawab yang lebih tinggi daripada dengan wewenang dan tanggung jawab yang ${ }^{\text {telah }}$ diberikan kepada tenaga kerja pada waktu sebelumnya.

\section{Indikator Kesempatan Promosi}

Menurut Hakim \& Darmawati (2015), ada lima indikator yang digunakan dalam mengukur kesempatan promosi, yaitu :

1) Promosi berdasarkan pengalaman kerja.

2) Promosi berdasarkan kompetensi.

3) Promosi berdasarkan loyalitas.

4) Promosi berdasarkan kesesuaian pendidikan.

\section{Pengembangan Hipotesis}

Pengaruh Stres Kerja Terhadap Turnover Intention

Menurut Dewi, Bagia, \& Susila (2014), stres kerja adalah ketegangan yang dialami karyawan karena adanya ketidakseimbangan antara tuntutan pekerjaan dengan kemampuan karyawan dalam menyelesaikan pekerjaanya.

Penelitian sejenis juga dilakukan oleh (Basri, 2017) dengan judul "Pengaruh stress kerja terhadap Turnover Intention melalui kepuasan kerja pada CV. Aneka Produksi". Variabel yang digunakan adalah Variabel Dependen (Y): Turnover Intention dan Variable Independen (X): Stres Kerja dan Variabel Mediasi (M): Kepuasan Kerja. Hasil penelitian ini diketahui Stres Kerja berpengaruh yang positif dan signifikan terhadap Turnover Intention pada CV. Aneka Produksi.

Pengaruh Kesempatan Promosi Terhadap Turnover Intention

Menurut Chairy \& Octora (2013), mendefinisikan promosi sebagai proses perubahan dari satu pekerjaan ke pekerjaan lain dalam wewenang dan tanggung jawab yang lebih tinggi daripada dengan wewenang dan tanggung jawab yang telah diberikan kepada tenaga kerja pada waktu sebelumnya.

Penelitian sejenis juga dilakukan oleh (Hakim \& Darmawati, 2015) dengan judul "Pengaruh Stres Kerja Dan Kesempatan Promosi Terhadap Turnover Intention pada Hotel Royal Ambarrukmo Yogyakarta". Variabel digunakan adalah (Y): Turnover Intention dan Variabel (X1): Stres Kerja dan (X2) : Kesempatan Promosi. Hasil penelitian menunjukkan bahwa stres kerja secara parsial berpengaruh positif 
dan signifikan terhadap turnover intention, kesempatan promosi secara parsial berpengaruh negatif dan signifikan terhadap turnover intention pada karyawan Royal Ambarukkmo Hotel Yogyakarta.

\section{Hipotesis}

H1 : Diduga Stres Kerja berpengaruh positif dan signifikan terhadap Turnover Intention

H2 : Diduga Kesempatan Promosi berpengaruh negatif dan signifikan terhadap Turnover Intention

\section{METODE PENELITIAN}

\section{Jenis Penelitian}

Jenis penelitian ini adalah Penelitian Kuantitatif, penelitian kuantitatif yaitu salah satu metode penelitian dimana data penelitian berupa angka-angka dan analisis menggunakan statistik (Sugiyono, 2015).

\section{Objek atau Lokasi Penelitian}

Objek penelitian merupakan lokasi dimana untuk mendapatkan sejumlah data yang akan dilakukan penelitan pada CV. Anisa Fadly Kabupaten Padang Pariaman yang beralamat di Desa Durian Gadang Kecamatan V Koto Kampung Dalam Kabupaten Padang Pariaman dijadikan sebagai objek dalam penelitian ini.

\section{Populasi}

Populasi dalam penelitian ini adalah seluruh karyawan CV. Anisa Fadly Kabupaten Padang Pariaman yang berjumlah 49 orang, dimana disini akan menguji tentang pengaruh stres kerja dan kesempatan promosi terhadap turnover intention.

\section{Sampel}

Dalam penelitian ini teknik pengambilan sampel yang digunakan adalah sampling jenuh dimana sampling jenuh adalah teknik pengambilan sampel bila semua anggota populasi digunakan sebagai sampel (Sugiyono, 2015). Sampel yang digunakan sebanyak 49 karyawan pada CV. Anisa Fadly Kabupaten Padang Pariaman.

\section{Teknik Pengumpulan Data}

\section{Kuisioner}

Kuisioner merupakan teknik pengumpulan data yang dilakukan dengan cara memberi beberapa pertanyaan dan pernyataan tertulis kepada responden untuk dijawabnya (Sugiyono, 2015). 
Tabel 2

Definisi Operasional Variabel

\begin{tabular}{|c|c|c|}
\hline Variabel & Definisi & Indikator \\
\hline Stres Kerja (X1) & $\begin{array}{l}\text { Perasaan yang menekan atau } \\
\text { merasa tertekan yang dialami } \\
\text { karyawan dalam menghadapi } \\
\text { pekerjaan }\end{array}$ & $\begin{array}{l}\text { 1. Konflik peran } \\
\text { 2. Karakteristik } \\
\text { Tugas } \\
\text { 3. Beban Kerja }\end{array}$ \\
\hline $\begin{array}{l}\text { Kesempatan Promosi } \\
\text { (X2) }\end{array}$ & $\begin{array}{l}\text { Suatu proses pemindahan karyawan } \\
\text { dari suatu jabatan ke jabatan lain } \\
\text { yang lebih tinggi }\end{array}$ & $\begin{array}{l}\text { 1. Promosi } \\
\text { berdasarkan } \\
\text { pengalaman kerja } \\
\text { 2. Promosi } \\
\text { berdasarkan } \\
\text { loyalitas } \\
\text { 3. Promosi } \\
\text { berdasarkan } \\
\text { kompetensi } \\
\text { 4. Promosrsi } \\
\text { berdasarkan } \\
\text { pendidikan }\end{array}$ \\
\hline Turnover Intention (Y) & $\begin{array}{l}\text { Keadaan dimana karyawan sebuah } \\
\text { organisasi memiliki perencanaan } \\
\text { untuk meninggalkan pekerjaannya, } \\
\text { atau kondisi dimana organisasi } \\
\text { memiliki rencana untuk memutus } \\
\text { hubungan kerja dengan } \\
\text { karyawannya }\end{array}$ & $\begin{array}{l}\text { 1. Adanya niat untuk } \\
\text { keluar (Intention } \\
\text { to quit) } \\
\text { 2. Pencarian } \\
\text { pekerjaan (Job } \\
\text { search) }\end{array}$ \\
\hline
\end{tabular}

Teknik Analisis Data

1. Uji Vadilitas

Uji vadilitas adalah suatu langkah pengujian yang dilakukan terhadap isi (konten) dari suatu instrumen yang digunakan dalam suatu penelitian (Sugiyono, 2015). Validitas suatu butir pertanyaan dapat dilihat dari output Statistical Program For Social Science (SPSS) pada pada tabel dengan judul Item-Total Statistisc.Suatu butir pertanyaan dikatakan valid jika nilai dari Corrected Item-Total Corrected > 0,30 . Uji validitas sebaiknya dilakukan secara terpisah pada lembar kerja yang berbeda antara satu konstruk variabel dengan konstruk variabel yang lain sehingga dapat diketahui butir-butir pertanyaan variabel mana yang paling banyak tidak valid. Sehingga pengambilan keputusan adalah:

a. Jika Corrected Item-Total Correlation> 0,30, maka dimensi tersebut valid

b. Jika Corrected Item-Total Correlation< 0,30, maka dimensi tersebut tidak valid

\section{Uji Reliabilitas}

Uji reliabilitas adalah uji terhadap instrumen yang bila digunakan beberapa kali untuk mengukur objek yang sama akan menghasilkan data yang sama (Sugiyono, 2015). Uji reabilitas dapat dilakukan secara bersama - sama terhadap 
seluruh butir pernyataan untuk lebih dari satu variabel, namun sebaiknya uji reliabilitas sebaliknya dilakukan pada masing - masing variabel pada lembar kerja yang berbeda sehingga dapat diketahui konstruk variabel mana yang tidak reliabel. Reliabilitas suatu konstuk variabel dikatakan baik jika memiliki nilai Cronbach's Alpha $>0,06$. Sehingga pengambilan keputusan adalah :

a. Jika $r$ Alpha positif, serta $r>0,06$ maka dimensi tersebut reliabel.

b. Jika $r$ Alpha positif, serta $r \leq 0,06$ maka dimensi tersebut tidak reliabel.

\section{Uji TCR (Tingkat Capaian Responden)}

Menghitung nilai Tingkat Capaian Responden (TCR) masing-masing kategori dari data deskriptif variabel. Rumus uji TCR (Hanum et al., 2015):

Keterangan :

$$
T C R=\frac{R s}{\mathrm{n}} \times 100 \%
$$

TCR : Tingkat Capaian Responden

$\mathrm{RS}$ : Rata-rata skor jawaban sampel

$\mathrm{n}$ : nilai skor jawaban

Sugiyono (2013), mengemukakan Kriteria jawaban responden untuk Tingkat Capaian Responden (TCR) adalah sebagai berikut:

Tabel 3

Rentang Skala TCR

\begin{tabular}{ccc}
\hline No & Angka & Keterangan \\
\hline 1 & $0 \%-54.9 \%$ & Tidak Baik \\
\hline 2 & $55 \%-64.9 \%$ & Kurang Baik \\
\hline 3 & $65 \%-79.9 \%$ & Cukup Baik \\
\hline 4 & $80 \%-89.9 \%$ & Baik \\
\hline 5 & $90 \%-100 \%$ & Sangat Baik \\
\hline
\end{tabular}

Sumber: Hanum et al., (2015)

\section{Uji asumsi klasik}

\section{Uji Normalitas}

Uji normalitas adalah pengujian untuk mengkaji kenormalan variabel yang diteleti apakah data tersebut berdistribusi normal atau tidak (Sugiyono, 2015). Indikator yang digunakan Uji kolmogrov-smirnov dengan pedoman yaitu:

a. Jika nilai signifikansi $>0,05$,,maka berdistribusi normal

b. Jika nilai signifikans $<0,05$, maka tidak berdistribusi normal

\section{Uji Multikolinearitas}

Uji multikonearitas bertujuan untuk menguji apakah model regresi ditemukan adanya korelasi antar variabel bebas (independen), model regresi yang baik seharusnya tidak terjadi korelasi diantara variabel independen (Ghozali, 2011). Indikator uji multikonearitas yaitu apabila nilai tolerance $>0,1$, dan Variance Inflation Factor (VIF) $<10$ maka tidak terjadi gejala multikonearitas sehingga tidak adanya pengaruh antara variabel yang satu dengan variabel yang lainnya.

\section{Uji Heteroskedastisitas}

Uji heteroskedatisitas bertujuan menguji apakah dalam model regresi terjadi ketidaksamaan varians dari residual satu pengamatan ke pengamatan yang lain. 
(Ghozali, 2011). Uji yang dipakai untuk mendeteksi ada atau tidaknya masalah heteroskedatisitas, yaitu :

\section{Uji Glejser}

Salah satu cara untuk melihat adanya problem heteroskedastisitas adalah dengan menggunakan uji glejser, dengan ketentuan jika nilai signifikasinya > 0,05 dapat disimpulkan model regresi tidak terjadi masalah heteroskedastisitas.

\section{Analisis Regresi Berganda}

Analisa regresi linear berganda adalah prosedur statistik untuk menganalisa hubungan antara variabel dependen dan variabel independen. Jika terdapat dua atau lebih variabel bebas maka menggunakan analisa regresi linear berganda (Prabowo \& Fathoni, 2016). Dalam penelitian ini digunakan persamaan regresi berganda sebagai berikut :

$$
\begin{aligned}
& \mathrm{Y}=\alpha+\beta 1 \mathrm{X} 1+\beta 2 \mathrm{X} 2+\mathrm{e} \\
& \mathrm{Y}=\text { Turnover Intention } \\
& \mathrm{X} 1=\text { Stres Kerja } \\
& \mathrm{X} 2=\text { Kesempatan Promosi } \\
& \alpha=\text { Koefisien Konstanta } \\
& \beta 1=\text { Koefisien regresi untuk Stres Kerja } \\
& \beta 2=\text { Koefisien untuk Kesempatan Promosi } \\
& \mathrm{e} \quad=\text { Standar error }
\end{aligned}
$$

\section{Uji Hipotesis}

\section{Uji F}

Uji Anova atau uji $\mathrm{F}$ adalah uji statistik yang fungsinya untuk mengetahui apakah secara bersamasama variabel independen mempunyai pengaruh signifikan atau tidak signifikan terhadap variabel dependen (Ardi \& Ninik Sukmasari, 2016). Dengan kriteria yang ditetapkan adalah :

a. Nilai Sig < 0,05 artinya secara bersama-sama ada pengaruh yang signifikan di antara seluruh variabel independen yang diuji terhadap variabel dependennya.

b. Nilai Sig > 0,05 artinya secara bersama-sama tidak ada pengaruh yang signifikan diantara seluruh variabel independen yang diuji terhadap variabel dependennya.

\section{Uji T}

Menurut Sugiyono (2015), uji statistik t pada dasarnya menunjukkan seberapa jauh pengaruh satu variabel independen secara individual dalam menerangkan variabel dependen. Pengujian dilakukan dengan menggunakan signifikan level 0,05 $(\alpha=5 \%)$. Penerimaan atau penolakan hipotesis dilakukan dengan kriteria:

a. Jika nilai signifikan > 0,05 maka hipotesis ditolak (koefisien regresi tidak signifikan). Ini berarti secara parsial variabel independen tidak mempunyai pengaruh secara signifikan terhadap variabel dependen.

b. Jika nilai signifikan $\leq 0,05$ maka hipotesis diterima (koefisien regresi signifikan). Ini berarti secara parsial variabel independen tersebut mempunyai pengaruh yang signifikan terhadap variabel dependen.

\section{3. $\mathbf{U j i} \mathbf{R}^{2}$}

Koefisien determinasi pada intinya mengukur seberapa jauh kemampuan model dalam menerangkan variasi variabel dependen. Nilai koefisien determinasi adalah antara nol dan satu. Nilai Adjusted $R^{2}$ yang kecil berarti kemampuan variabel- 
variabel independen dalam menjelaskan variasi variabel dependen sangat terbatas, dimana hal yang ditunjukkan oleh besarnya koefisien determinasi antara nol (0) dan (1). Koefisien determinasi nol variabel independen sama sekali tidak berpengaruh terhadap variabel dependen. (Sugiyono, 2015).

\section{HASIL DAN PEMBAHASAN}

\section{Teknik Analisis Data}

\section{Uji Validitas}

Tabel 4

Uji Validitas Variabel Stres Kerja (X1)

Corrected Item-

Total Correlation

Standar Pengukuran

Keterangan

\begin{tabular}{cccc}
\hline Sk1 & 0,750 & 0,30 & Valid \\
\hline Sk2 & 0,439 & 0,30 & Valid \\
\hline Sk3 & 0,409 & 0,30 & Valid \\
\hline Sk4 & 0,411 & 0,30 & Valid \\
\hline Sk5 & 0,602 & 0,30 & Valid \\
\hline Sk7 & 0,709 & 0,30 & Valid \\
\hline Sk8 & 0,662 & 0,30 & Valid \\
\hline Sk9 & 0,662 & 0,30 & Valid \\
\hline Sk10 & 0,709 & 0,30 & Valid \\
\hline Berdasan & 0,750 & 0,30 & Valid
\end{tabular}

Berdasarkan hasil dari perhitungan uji validitas variabel X1 (Stres Kerja) terhadap 49 responden, didapatkan bahwa semua butir pernyataan dinyatakan valid. Hal ini ditunjukkan dengan nilai Corrected Item-Total Correlation $>0,30$, sehingga dapat dilakukan untuk penelitian lebih lanjut.

Tabel 5

Uji Validitas Variabel Kesempatan Promosi (X2)

\begin{tabular}{lrcc}
\hline & $\begin{array}{c}\text { Corrected Item-Total } \\
\text { Correlation }\end{array}$ & $\begin{array}{c}\text { Standar } \\
\text { Pengukuran }\end{array}$ & Keterangan \\
\hline kp1 & 0,454 & 0,30 & Valid \\
\hline kp2 & 0,463 & 0,30 & Valid \\
\hline kp3 & 0,499 & 0,30 & Valid \\
\hline kp4 & 0,401 & 0,30 & Valid \\
\hline kp5 & 0,682 & 0,30 & Valid \\
\hline kp6 & 0,629 & 0,30 & Valid \\
\hline kp7 & 0,564 & 0,30 & Valid \\
\hline kp8 & 0,444 & 0,30 & Valid \\
\hline kp9 & 0,407 & 0,30 & Valid \\
\hline
\end{tabular}

Berdasarkan hasil dari perhitungan uji validitas variabel X2 (Kesempatan Promosi) terhadap 49 responden, didapatkan bahwa semua butir pernyataan dinyatakan valid. Hal ini ditunjukkan dengan nilai Corrected Item-Total Correlation yang lebih besar dari 0,30, sehingga dapat dilakukan untuk penelitian lebih lanjut. 
Tabel 6

Uji Validitas Variabel Turnover Intention (Y)

\begin{tabular}{lrrc}
\hline & $\begin{array}{c}\text { Corrected } \\
\text { Item-Total } \\
\text { Correlation }\end{array}$ & $\begin{array}{c}\text { Standar } \\
\text { Pengukuran }\end{array}$ & Keterangan \\
\hline To1 & 0,644 & 0,30 & Valid \\
\hline Toi2 & 0,797 & 0,30 & Valid \\
\hline Toi3 & 0,499 & 0,30 & Valid \\
\hline Toi4 & 0,568 & 0,30 & Valid \\
\hline Toi5 & 0,373 & 0,30 & Valid \\
\hline Toi6 & 0,459 & 0,30 & Valid \\
\hline Toi7 & 0,501 & 0,30 & Valid \\
\hline Toi8 & 0,417 & 0,30 & Valid \\
\hline Toi9 & 0,644 & 0,30 & Valid \\
\hline Toi10 & 0,797 & 0,30 & Valid \\
\hline
\end{tabular}

Berdasarkan hasil dari perhitungan uji validitas variabel Y (Turnover Intention) terhadap 49 responden, didapatkan bahwa semua butir pernyataan dinyatakan valid. Hal ini ditunjukkan dengan nilai Corrected Item-Total Correlation yang lebih besar dari 0,30 , sehingga dapat dilakukan untuk penelitian lebih lanjut.

Tabel 7

Uji Reliabilitas

\begin{tabular}{llcc}
\hline No. & Variabel & $\begin{array}{c}\text { Cronbach's } \\
\text { Alpha }\end{array}$ & Reliabilitas \\
\hline $\mathbf{1}$ & Stres Kerja & 0,761 & Reliabel \\
\hline $\mathbf{2}$ & Kesempatan Promosi & 0,742 & Reliabel \\
\hline $\mathbf{3}$ & Turnover Intention & 0,754 & Reliabel \\
\hline
\end{tabular}

Dari hasil uji reliabilitas, dihasilkan nilai Cronbach's Alpha untuk variabel penelitian Stres Kerja, Kesempatan Promosi, dan Turnover Intention lebih dari 0,60 yang memberikan hasil bahwa variabel yang diteliti dapat dikatakan reliabilitas.

Uji TCR

Tabel 8

Deskripsi Variabel Stres Kerja (X1)

\begin{tabular}{rrrrll}
\hline \multirow{2}{*}{ No. Item } & N & Rata-rata & \multirow{2}{*}{ TCR (\%) } & & \multirow{2}{*}{ Kriteria } \\
\hline 1 & 49 & 4.37 & 87.30 & Baik \\
\hline 2 & 49 & 3.92 & 78.40 & Cukup Baik \\
\hline 3 & 49 & 3.9 & 78.0 & Cukup Baik \\
\hline 4 & 49 & 4 & 80.0 & Baik \\
\hline 5 & 49 & 4.06 & 81.2 & Baik \\
\hline 6 & 49 & 4.33 & 86.50 & Baik \\
\hline 7 & 49 & 3.94 & 78.80 & Cukup Baik \\
\hline 8 & 49 & 3.94 & 78.80 & Cukup Baik \\
\hline 9 & 49 & 4.33 & 86.50 & Baik \\
\hline 10 & 49 & 4.37 & 87.30 & Baik \\
\hline \multicolumn{2}{l}{ Rata-rata TCR } & & 82.30 & Baik \\
\hline
\end{tabular}

Dari tabel diatas maka dapat dilihat bahwa item pernyataan nomor tiga merupakan persentase paling rendah sebesar $78 \%$ dan item pernyataa nomor sepuluh merupakan persentase paling tinggi sebesar $87,30 \%$. Kesimpulan rata-rata dari 
tanggapan responden terhadap variabel stress kerja berada pada tingkatan Baik, yaitu sebesar $82.30 \%$

Tabel 9

Deskripsi Variabel Kesempatan Promosi (X2)

\begin{tabular}{rrrrl}
\multicolumn{1}{c}{$\begin{array}{c}\text { No. } \\
\text { Item }\end{array}$} & N & \multicolumn{1}{c}{$\begin{array}{c}\text { Rata- } \\
\text { rata }\end{array}$} & \multicolumn{1}{l}{ TCR } & Kriteria \\
\hline 1 & 49 & 4.22 & 84.50 & Baik \\
\hline 2 & 49 & 3.71 & 74.30 & Cukup Baik \\
\hline 3 & 49 & 3.94 & 78.80 & Cukup Baik \\
\hline 4 & 49 & 3.82 & 76.30 & Cukup Baik \\
\hline 5 & 49 & 3.9 & 78.0 & Cukup Baik \\
\hline 6 & 49 & 4.24 & 84.90 & Baik \\
\hline 7 & 48 & 3.94 & 78.80 & Cukup Baik \\
\hline 8 & 49 & 3.96 & 79.20 & Cukup Baik \\
\hline 9 & 49 & 3.76 & 75.10 & Cukup Baik \\
\hline 10 & 49 & 4.1 & 82.0 & Baik \\
\hline Rata-rata TCR & & 79.20 & Cukup Baik \\
\hline
\end{tabular}

Dari tabel diatas maka dapat dilihat bahwa item pernyataan nomor dua merupakan persentase paling rendah sebesar $74,30 \%$ dan item pernyataan nomor enam merupakan persentase paling tinggi sebesar $84,90 \%$. Kesimpulan rata-rata dari tanggapan responden terhadap variabel kesempatan promosi berada pada tingkatan Cukup Baik, yaitu sebesar 79,20\%

Tabel 10

Deskripsi Variabel Turnover Intention (Y)

\begin{tabular}{rrrrl}
\hline $\begin{array}{c}\text { No. } \\
\text { Item }\end{array}$ & N & Rata-rata & TCR & Kriteria \\
\hline 1 & 49 & 4 & 80.0 & Baik \\
\hline 2 & 49 & 4.06 & 81.20 & Baik \\
\hline 3 & 49 & 3.88 & 77.60 & Cukup Baik \\
\hline 4 & 49 & 3.94 & 78.80 & Cukup Baik \\
\hline 5 & 49 & 3.94 & 78.80 & Cukup Baik \\
\hline 6 & 49 & 4.37 & 87.30 & Baik \\
\hline 7 & 49 & 4.33 & 86.50 & Baik \\
\hline 8 & 49 & 3.76 & 75.10 & Cukup Baik \\
\hline 9 & 49 & 4 & 80.0 & Baik \\
\hline 10 & 49 & 4.06 & 81.20 & Baik \\
\hline & Rata-rata & & 80,70 & Baik \\
\hline
\end{tabular}

Dari tabel diatas maka dapat dilihat bahwa item pernyataan nomor delapan merupakan persentase paling rendah sebesar $75,10 \%$ dan item pernyataan nomor enam merupakan persentase paling tinggi sebesar $87,30 \%$. Kesimpulan rata-rata dari tanggapan responden terhadap variabel kesempatan promosi berada pada tingkatan Baik, yaitu sebesar $80,70 \%$ 
Tabel 11

Uji Normalitas

\begin{tabular}{lrr}
\hline & Standardized Residual & \\
\hline Kolmogorov-Smirnov Z & 0,415 \\
Asymp. Sig. (2-tailed) & 0,995 \\
\hline
\end{tabular}

Dengan data yang dapat dilihat berdasarkan hasil olahan data diatas bahwa nilai signifikansi sebesar 0,995 >0,05, sehingga dapat ditarik kesimpulan bahwa data yang diolah berdistribusi normal.

Tabel 12

Uji Multikolinearitas

\begin{tabular}{|c|c|c|c|}
\hline & & \multicolumn{2}{|c|}{ Collinearity Statistics } \\
\hline \multicolumn{2}{|c|}{ Uji Model } & Tolerance & VIF \\
\hline \multirow[t]{3}{*}{1} & (Constant) & & \\
\hline & sk: stres kerja & .958 & 1.043 \\
\hline & $\begin{array}{l}\mathrm{kp} \text { : kesempatan } \\
\text { promosi }\end{array}$ & .958 & 1.043 \\
\hline
\end{tabular}

Berdasarkan uji multikonearitas bahwa menunjukkan nilai tolerance dari setiap variabel bebas $0,958>0,1$ dan nilai VIF $1,043<10$, maka kesimpulannya tidak terjadi masalah multikonearitas.

\section{Uji Heteroskedatisitas}

Tabel 13

Uji Glejser

\begin{tabular}{lcr} 
Model & $\mathrm{t}$ & Sig. \\
\hline $1($ Constant $)$ & 2.415 & .020 \\
\hline sk : stres kerja & -2.001 & .051 \\
\hline $\mathrm{kp}:$ kesempatan promosi & -.704 & .485 \\
\hline
\end{tabular}

Berdasarkan hasil uji gletser diatas dapat diketahui bahwa nilai signifikan Stres Kerja 0,051 > 0,05 dan nilai signifikan Kesempatan Promosi 0,485 > 0,05, maka dapat disimpulkan model regresi tidak mengandung masalah heteroskedatisitas.

Analisis Regresi Linear Berganda

Tabel 14

Hasil Uji Regresi Linear Berganda

Coefficients $^{\mathbf{a}}$

\begin{tabular}{|c|c|c|c|c|}
\hline \multirow[b]{2}{*}{ Model } & \multicolumn{2}{|c|}{ Unstandardized Coefficients } & \multirow[b]{2}{*}{$\mathrm{t}$} & \multirow[b]{2}{*}{ Sig. } \\
\hline & $\mathrm{B}$ & Std. Error & & \\
\hline 1 (Constant) & 7.901 & 5.002 & 1.580 & .121 \\
\hline sk : stres kerja & .790 & .073 & 10.872 & .000 \\
\hline $\begin{array}{l}\mathrm{kp}: \text { kesempatan } \\
\text { promosi }\end{array}$ & -.002 & .087 & -.017 & .986 \\
\hline
\end{tabular}


Berdasarkan hasil regresi yang didapat maka dibuat persamaan linear berganda sebagai berikut :

$\mathrm{Y}=7,901+0,790(\mathrm{X} 1)+(-0.02)(\mathrm{X} 2)$

Persamaan regresi linear berganda diatas mempunyai arti sebagai berikut:

1. Konstanta mempunyai nilai positif sebesar 7,901. Hal ini berarti apabila stress kerja dan kesempatan promosi CV. Anisa Fadly Kabupaten Padang Pariaman bernilai nol, maka turnover karyawan masih bernilai tetap 7,901.

2. Nilai koefisien regresi stress kerja adalah 0,790 artinya apabila stress kerja meningkat sebsesar satu satuan, maka turnover intention meningkat 0,790 .

3. Nilai koefisien regresi kesempatan promosi adalah -0.02 artinya apabila kesempatan promosi menurun satu satuan maka turnover intention berkurang 0,02 .

\section{Uji Hipotesis}

Tabel 15

Uji T

\begin{tabular}{llrr} 
Model & T & Sig. \\
\hline \multirow{2}{*}{1} & (Constant) & 1.580 & .121 \\
\cline { 2 - 4 } & sk : stres kerja & 10.872 & .000 \\
\cline { 2 - 4 } & kp : kesempatan promosi & -.017 & .986 \\
\hline
\end{tabular}

Berdasarkan hasil uji t pada tabel diatas dapat dilkakukan analisa sebagai berikut

1. Hasil uji t stress kerja terhadap turnover intention diperoleh thitung $(10,872)>t$ tabel (1.67655) dan nilai signifikansi sebesar 0,000. Hal ini menunjukkan adanya pengaruh positif dan signifikan $(0,000<0,05)$. Sehingga menerima hipotesis $\mathrm{H} 1$ yang menyatakan stress kerja berpengaruh positif dan signifikan terhadap turnover intention.

2. Hasil uji t kesempatan promosi terhadap turnover intention diperoleh thitung ($0,17)<\mathrm{t}$ tabel (1.67655) dan nilai signifikansi sebesar 0,986. Hal ini menunjukkan adanya pengaruh yang negatif dan tidak signifikan $(0,986>0,05)$. Sehingga menolak hipotesis yang menyatakan kesempatan promosi berpengaruh negatif dan signifikan terhadap turnover intention.

Uji F

Tabel 16

ANOVA $^{b}$

\begin{tabular}{|c|c|c|c|}
\hline \multicolumn{2}{|c|}{ Model } & \multirow[b]{2}{*}{61700} & Sig. \\
\hline 1 & Regression & & $.000^{\mathrm{a}}$ \\
\hline & \multicolumn{3}{|l|}{ Residual } \\
\hline & Total & & \\
\hline
\end{tabular}


stres kerja dan kesempatan secara bersama-sama dapat menjelaskan variabel turnover intention.

$\mathbf{U j i} \mathbf{R}^{2}$

Tabel 17

Hasil uji Koefisien Regresi Determinasi $\left(\mathbf{R}^{2}\right)$

\begin{tabular}{lrrrrr}
\hline Model & R & \multicolumn{2}{c}{ R Square } & Adjusted R Square & $\begin{array}{c}\text { Std. Error of the } \\
\text { Estimate }\end{array}$ \\
\hline 1 & $.853^{\mathrm{a}}$ & .728 & .717 & 2.51181 \\
\hline
\end{tabular}

Besarnya koefisien determinasi dapat dilihat pada Adjusted $R$ Square adalah sebesar 0,717, yang mempunyai arti bahwa turnover intention dijelaskan oleh variabel stress kerja dan kesempatan promosi sebesar $71,7 \%$, sedangkan sebesar $28,3 \%$ dijelaskan oleh variabel lain yang tidak diteliti dalam penelitian ini contohnya variabel kepuasan kerja dan kompensasi.

Pembahasan

1. Pengaruh Stres Kerja Terhadap Turnover Intention pada CV. Anisa Fadly Kabupaten Padang Pariaman

Berdasarkan hasil pengujian hipotesis pertama, ditemukan bahwa variabel stress kerja berpengaruh positif dan signifikan terhadap turnover intention pada CV. Anisa Fadly Kabupaten Padang Pariaman. Besaran koefisien regresi variabel stress kerja 0,790 dan signifikansinya sebesar 0,000 yang lebih kecil dari 0,05. Hal ini dapat diartikan bahwa variabel stres kerja berpengaruh positif dan signifikan terhadap turnover intention, dengan demikian, hipotesis pertama $(\mathrm{H} 1)$ dalam penelitian ini yang menyatakan bahwa stres kerja berpengaruh positif dan signifikan terhadap turnover intention pada CV. Anisa Fadly Kabupaten Padang Pariaman, dinyatakan dapat diterima.

Hal ini berarti bahwa stress kerja bertambah akan menyebabkan meningkatnya turnover intention pada CV. Anisa Fadly Kabupaten Padang Pariaman, hal tersebut mengembangkan pernyataan Robbins dan Judge (2006) bahwa stress kerja dapat mempengaruhi emosi, proses berpikir, dan kondisi fisik dan mental seseorang. Karyawan yang mengalami stress kerja yang terjadi akan menimbulkan terjadinya turnover intention. Turnover intention merupakan keadaan dimana karyawan memiliki keinginan untuk keluar dari organisasi karena suatu alasan. Hasil penelitian ini juga sejalan dengan penelitian Basri (2017) yang menunjukkan bahwa stress kerja memiliki pengaruh yang positif dan signifikan terhadap turnover intention karyawan CV. Aneka Produksi.

\section{Pengaruh Kesempatan Promosi Terhadap Turnover Intention pada CV. Anisa} Fadly Kabupaten Padang Pariaman

Berdasarkan hasil pengujian hipotesis kedua, ditemukan bahwa variabel kesempatan promosi berpengaruh negatif dan tidak signifikan terhadap turnover intention pada CV. Anisa Fadly Kabupaten Padang Pariaman. Besaran koefisien regresi variabel kesempatan promosi -0,02 dan signifikansinya sebesar 0,986 yang lebih besar dari 0,05. Hal ini dapat diartikan bahwa variabel kesempatan promosi berpengaruh negatif dan tidak signifikan terhadap turnover intention, dengan 
demikian, hipotesis kedua (H2) dalam penelitian ini yang menyatakan bahwa kesempatan promosi berpengaruh negatif dan tidak signifikan terhadap turnover intention pada CV. Anisa Fadly Kabupaten Padang Pariaman, dinyatakan ditolak.

Hal ini bermakna tingkat turnover intention akan tetap terjadi pada CV. Anisa Fadly Kabupaten Padang Pariaman, meskipun ada atau tidaknya tingkat kesempatan promosi di perusahaan tersebut.Penelitian sejenis ini sebelumya juga dilakukan oleh (Hakim \& Darmawati, 2015) menjelaskan bahwa kesempatan promosi berpengaruh negatif dan signifikan terhadap turnover inention pada karyawan Hotel Royal Ambarrukmo Yogyakarta.

\section{KESIMPULAN DAN SARAN}

\section{Kesimpulan}

Berdasarkan hasil penelitian yang telah dilkakuan di CV. Anisa Fadly Kabupaten Padang Pariaman dan hasil pembahasannya, maka pada bab ini penulis dapat menarik beberapa kesimpulan sebagai berikut :

1. Berdasarkan hasil penelitan yang dilakukan, menunjukkan bahwa stres kerja berpengaruh positif dan signifikan terhadap turnover intention pada CV. Anisa Fadly Kabupaten Padang Pariaman. Ini dapat dilihat dari hasil uji t diperoleh $\mathrm{t}$ hitung $10,872>\mathrm{t}$ tabel $(1,6772)$ dan nilai signifikan sebesar $0,000<0,05$. Maka hipotesis diterima karena mendukung hipotesis (H1) bahwa stress kerja berpengaruh positif dan signifikan terhadap turnover intention.

2. Berdasarkan hasil penelitan yang dilakukan, menunjukkan bahwa kesempatan promosi berpengaruh negatif dan tidak signifikan terhadap turnover intention pada CV. Anisa Fadly Kabupaten Padang Pariaman. Ini dapat dilihat dari hasil uji t diperoleh $\mathrm{t}$ hitung $(-0,017)<\mathrm{t}$ tabel $(1,6772)$ dan nilai signifikan sebesar $0,986>$ 0,05. Maka hipotesis ditolak, karena tidak mendukung hipotesis (H2) bahwa kesempatan promosi berpengaruh positif dan signifikan terhadap turnover intention.

3. Berdasarkan hasil Adjusted $R$ Square didapat besarnya hasil koefisien determinasinya sebsesar 0,717 , yang artinya bahwa turnover intention dijelaskan oleh variabel stress kerja dan kesempatan promosi sebesar $72 \%$, sedangkan sisanya sebesar $28 \%$ dijelaskan oleh variabel lain yang tidak diteliti dalam penelitian ini contohnya variabel kepuasan kerja dan kompensasi.

\section{UCAPAN TERIMAKASIH}

Dengan selesainya penulisan artikel ini, penulis mengucapkan terima kasih kepada pihak-pihak yang membantu selama proses penulisan.

1. Bapak Febryandhie Ananda, SE, M.Si, selaku Ketua di STIE "KBP” Padang.

2. Ibu Lidya Martha, SE, MM selaku Wakil Ketua di STIE "KBP” Padang.

3. Ibu Febsri Susanti, SEI, MM selaku Ketua Program Studi Manajemen di STIE "KBP" Padang.

4. Ibu Maria Magdalena, S.Pd, MM, selaku Penasehat Akademik Program Studi Manajemen di STIE “KBP” Padang.

5. Ibu Riri Mayliza, SE, MM, selaku Pembimbing Proposal Skripsi di STIE "KBP” Padang 


\section{DAFTAR PUSTAKA}

Aldi, Y., \& Susanti, F. (2019). Pengaruh Stress Kerja Dan Motivasi Kerja Terhadap Prestasi Kerja Karyawan Pada PT. Frisian Flag Indonesia Wilayah Padang. https://doi.org/10.31227/osf.io/et4rn

Ardi, R. P., \& Ninik Sukmasari. (2016). Pengaruh Disiplin Kerja , Promosi Jabatan dan Kompensasi Terhadap Kinerja Pegawai pada Dinas Kebudayaan Pariwisata Pemuda dan Olahraga Kabupaten Rembang Effect of Work Discipline, Promotion and Compensation towards Employee Performance at the Department. Jurnal Manajemen, 7(2), 105-110.

Basri, M. H. (2017). Pengaruh stres kerja terhadap turnover intentions melalui kepuasan kerja pada cv. aneka produksi. Jurnal Ilmu Manajemen, 5(2), 1-7.

Chairy, \& Octora, V. B. (2013). Pengaruh Efikasi Diri, Sikap terhadap Pekerjaan, dan Kesempatan Promosi Terhadap Intensi Berwirausaha. Jurnal Manajemen, 17(3), 337-350.

Dewi, C. N. C., Bagia, I. W., \& Susila, G. P. A. J. (2014). Pengaruh Stres Kerja Dan Kepuasan Kerja Terhadap Kinerja Karyawan Pada Bagian Tenaga Penjualan UD Surya Raditya Negara. E-Journal Urusan Manajemen, 2(2), 1-9.

Fendi, Z., \& Susanti, F. (2018). Pengaruh Kepuasan Kerja Terhadap Turnover Intention Dengan Komitmen Organisasi Sebagai Variabel Intervening Pada CV. Belibis Pariaman. https://doi.org/10.31227/osf.io/wumgx

Ghozali, I. (2011). Aplikasi Analisis Multivariate Dengan Program IBM SPSS 20. In book (pp. 1-298). Semarang: Badan Penerbit Universitas Diponegoro.

Hakim, M. L., \& Darmawati, A. (2015). Pengaruh Stres Kerja dan Kesempatan Promosi Terhadap Turnover Intention. Jurnal Manajemen, 10.

Kamener, D. (2017). Faktor - Faktor Yang Mempengaruhi Kualitas Strategi Bersaing Industri Ukm Bordiran / Sulaman Di Kota Padang. Journal of Economic and Economic Education, 5(1), 90-105. https://doi.org/doi.org/10.22202/economica.2015.5.1.688

Mahardiani, Y., \& Pradhanawati, A. (2013). Pengaruh Stres Kerja dan Lingkungan Kerja Fisik terhadap Kinerja Karyawan Outsourcing pada PT . Bank Jateng Cabang Koordinator dan Cabang Pembantu Wilayah Kota Semarang. Jurnal Administrasi Bisnis, 2(1), 98-104.

Malma, M. A., Rodhiyah, \& Dewi, R. S. (2014). Pengaruh Kompensasi dan Motivasi 
Kerja Terhadap Turnover Intention Melalui Stress Kerja Karyawan PT. Bank Tabungan Negara Kantor Cabang Semarang. Journal Of Sosial and Political Of Science, 3(1), 1-12. Retrieved from http://ejournal-s1.undip.ac.id/index.php/

Mayliza, R. (2019). Pengaruh Kompensasi Finansial, Lingkungan Kerja Dan Motivasi Kerja Terhadap Kinerja Pegawai Pada Kantor PDAM Kota Payakumbuh. https://doi.org/10.17605/OSF.IO/DZXAF

Nazenin, S., \& Palupiningdyah. (2014). Peran Stres Kerja Dan Kepuasan Kerja Untuk Mengurangi Turnover Intention. Jurnal Dinamika Manajemen, 5(2), 220-227.

Oktaviani, R. M., \& Nurhayati, I. (2014). Pengaruh Komitmen Profesi terhadap Turnover Intention Dengan Kepuasan Kerja Sebagai Variabel Pemediasi. Jurnal Bisnis Dan Ekonomi (JBE), 21(1), 83-98.

Putri, A. T. (2015). Pengaruh Promosi dan Mutasi Jabatan Terhadap Kepuasan Kerja Karyawan pada Kanwil II PT. Pegadaian (Persero) Pekanbaru. Jurnal Manajemen, 2(1), 1-11.

Roring, M. Y., Soegoto, A. S., \& Dotulong, L. (2014). Stres Kerja dan Lingkungan Kerja Pengaruhnya terhadap Prestasi Pegawai pada Biro Umum SETDA Provinsi Sulawesi Utara. Jurnal Emba, 2(3), 1359-1368.

Rikardo, T., \& Susanti, F. (2019). Pengaruh Job Insecurity, Dan Beban Kerja Terhadap Stres Kerja Pada PT Garda Total Security Padang. https://doi.org/10.31227/osf.io/pfe72

Saeka, I. P. A. P., \& I Wayan Suana. (2016). Pengaruh kepuasan kerja karyawan terhadap komitmen organisasional dan. E-Jurnal Manajemen Unud, 5(6), 3736-3760.

Sugiyono. (2015). Statistik Nonparametris Untuk Penelitian. Book. Bandung: CV. Alvabeta.

Susanto, R. (2018). Pengawasan Dan Lingkungan Kerja Terhadap Kinerja Karyawan PT. Bussan Auto Finance. https://doi.org/10.31227/osf.io/m3kge

Syahronica, G., Hakam, M. S., \& Ruhana, I. (2015). Pengaruh kepuasan kerja dan stres kerja terhadap turnover intention ( studi pada karyawan departemen dunia fantasi pt pembangunan. Jurnal Administrasi Bisnis (JAB), 20(1), 1-6.

Yanuarmawan, D. (2012). Pengaruh Promosi Jabatan Terhadap Kinerja Karyawan Dikaji Menurut Teori Alderfer (Studi di PT. BPR Gunung Ringgit Malang). Jurnal Akuntansi Dan Ekonomi Bisnis, 1(1), 57-72. 